\title{
The Political Economy of Prison Labour: From Penal Welfarism to the Penal State
}

\author{
Christoph Scherrer and Anil Shah, University of Kassel, Germany
}

\begin{abstract}
The article traces the return of prison labour for commercial purposes in the United States. In the age of Fordism, work for commercial purposes was prohibited in prisons; the emphasis was on rehabilitation. This "penal welfarism" gave way to a "penal state" of extremely high incarceration rates and exploitative prison labour. While this shift mirrors the turn to neo-liberalism, it is also the result of specific labour market conditions and racial discrimination.
\end{abstract}

\section{KEYWORDS}

prison labour; racism; disciplining of the superfluous labour force; United States

Prisoners are rarely visible in everyday life. This holds true all the more so for their labour behind iron bars. They also seem to be quite invisible in the field of labour studies. While an increasing number of inmates around the world are forced to work, their working conditions have received scant attention. The relationship between incarceration rates, prison labour, profit interests and the labour market is also understudied.

This article addresses both areas of neglect. We want to call attention to the miserable remuneration of prison labour and we want to contribute to a better theoretical understanding of the drivers of prison labour. We have chosen the United States of America as our empirical example. It is the country with the highest per capita incarceration rate in the world, and where inmates are not only working to maintain overall prison operations but also for profitable industries. But most important for theoretical considerations, the high incarceration rates and prison labour for commercial purposes have not been a permanent feature of the American penal system. In fact, in the Fordist period (1940s to 1970s) the level of the prison population was low, work for commercial purposes was prohibited, and emphasis was, at least rhetorically, placed on the reintegration of felons into society. This period, perhaps a bit euphemistically called "penal welfarism", gave way to the current situation of a "penal state". It mirrors the shift from Fordism, the period of a social compromise between capital and labour, to today's neo-liberalism, a period characterised by the hegemony of private property holders. The analysis of this shift will shed light on the relationship between modes of production, the labour market and criminalisation.

The parallels between these two shifts, however, should be treated with caution. Just as neoliberalism is not without contradictions, resistance and manifold manifestations across time and nations 
(Cerny, 2008), the penal state comes also in different forms and intensities.

In the case of the United States, racism leaves a huge imprint on the system of state-sanctioned punishment. Therefore, we will not only extend our look backwards to the nineteenth century to trace the legacy of slavery, but also approach the topic of prison labour from a political economy perspective that includes matters of race.

The article is structured as follows. First, we develop our theoretical approach of (multi-layered) discourse analysis. Second, we portray the role of incarceration policies, prison labour and socioeconomic conditions in the USA from the beginning of the nineteenth century until the time of Fordism. Against this background, we will then show how the changes of these conditions in the 1970s and 1980s have transformed the role of prisons and prison labour. Subsequently, the diverse drivers of prison labour will be explored in more detail and their interrelation will be addressed.

\section{Theoretical Approaches to Prison Labour}

The discipline of criminology covers the topic prison labour from the perspective of the possibilities for rehabilitation of felons (Price, Pierson and Coleman, 2012). Criminology, however, does not explain the occurrence of commercial prison labour. The field of political economy provides only a few and partially contradictory explanations for the phenomenon of prison labour. If one follows Karl Marx' reasoning about the formal and the real subsumption of labour, then the exertion of direct compulsion to work - that is, the formal subsumption of labour - does belong to the early days of capitalism. Developed capitalism, on the other hand, would be characterised by real subsumption of labour. Since connections to self-sustaining agriculture are cut, there would be no alternative for those without capital than wage labour, and the work cycle of machines as well as the digital monitoring of labour processes within administrations would make the direct exertion of physical force as an incentive to work redundant (Schmiede, 1988). In the mid-1970s criminological reform-oriented actors in the USA even imagined the impending abolition of prisons (Dodge, 1975). But just as slave labour exists globally today next to free wage work, prison labour is not only still here, but is gaining steam.

From the perspective of Georg Rusche and Otto Kirchheimer (1968 [1939]), the reintroduction of prison labour without the intention of rehabilitation is not so surprising. The two authors analysed prison labour in relation to labour market conditions eighty years ago. They argue that the supply and demand conditions of the labour market as well as the condition of public budgets influence the type of penalties applied by the state. For example, in case of an oversupply of labour the main motive for prison labour will not be rehabilitation but the disciplining of labour. While we acknowledge the value of their work, we share the critique of David Garland (1990: 108) that for Rusche and Kirchheimer, as well as for their "rediscoverers" Dario Melossi and Massimo Pavarini (1981), economic factors are determinant in the last instance. In comparison, we find the approach of Garland more convincing. A complex institution such as punishment requires an analysis from different perspectives, whereby the exploration of causal connections among a variety of factors should be prioritised over the identification of one main factor. Therefore, Garland drew on insights not only from the Marxist tradition but also from the sociological works of Durkheim, Foucault, Weber, and Elias (Garland, 1985). In Garland's work racism played only a subordinated role. More recent literature, however, 
considers racism as a rather important driver of the rapid increase of the prison population (Wacquant, 2009; Alexander, 2010).

For an understanding of the return of commercial prison labour in the United States, we will look at the manifold developments in the field of punishment. The different theoretical perspectives will find an integrating link in Ernesto Laclau's discourse analysis. His understanding of discourse includes collective and individual practices as well as verbal and written utterances (Laclau, 1990). His main premise is radical contingency which, contrary to some of his critics, does not deny structures. The closure of structures is denied, but not their existence. Contingency should not be confused with randomness. It should be understood as a horizon of possibilities shaped by specific conditions (Wullweber and Scherrer, 2011). Therefore, one has to analyse on the one hand the interaction of various structuring discourses (in terms of meaning making and praxis) and to explore on the other hand contingency - that is, the possibilities for change. Applied to our topic, this means identifying the various elements of the prison labour discourse, including their genesis. The task is to trace the interaction of political, economic and socio-cultural developments which have brought about the return of prison labour for commercial purposes.

We will approach this task by first describing the different phases of the historical development of confinement and prison labour in the United States. Against this backdrop, we will identify the main elements of the current discourse of prison labour. Among these elements is the disciplining of those who are not in demand in the labour market and are, therefore, in a vulnerable position. This element gains in salience with the increasing pressure on public budgets (the two arguments of Rusche and Kirchheimer). Another element is the racist discourse which excludes significant parts of the AfricanAmerican population from the labour market and marginalises Latin American migrants (the argument of Alexander). In addition, one has to take into account the lobbying by private prison corporations. The analysis of the interplay of these discourses allows us to reflect on the opportunities as well as the limits for (commercial) prison labour.

\section{Incarceration and Prison Labour: Oscillating between Re-socialisation and Profit}

Prison labour is not a novelty in modern history. The concept mainly feeds on two ideas of limited compatibility: re-socialisation through work and economic utilisation of the workforce. After the American Revolution, longer prison sentences became prevalent as punishments for male delinquents. This was seen as the more appropriate punitive form compared to the previously common hanging, torturing or pillorying. The extended time in prison was supposed to be conducive to atonement and the work to be conducive to acquiring skills and lawful habits. After 1820, however, a contractual labour system became dominant on a large scale, where the prisons' operators were renting out the prisoners to private persons and companies (McLennan, 2008). In the Southern states, after the emancipation of the slaves, this system took on a massive scale, in a sense as a substitute for slavery. The old and new elites of the South remained interested to an equal extent in keeping up this forced labour (Lichtenstein, 1997), both to supply workers for the plantations, but also to build and maintain infrastructure. To achieve this, the threshold for arrests were lowered (the so-called Pig Laws) and 
prison terms extended. Since the private users of the prisoners' labour power did not own the prisoners, their interest in maintaining the exploited prisoners was even less than in in the case of slaves. Work conditions were accordingly brutal (Oshinsky, 1996). An intended side effect was the disciplining of the black population and free workers. In case of protests, the latter had to fear losing their workplace to a prisoner (Mancini, 1996).

Nevertheless, rebellions did take place, and an armed revolt of mineworkers in the periphery of the Southern states (Eastern Tennessee) in 1891 accelerated the turning away from the contract labour system (Mancini, 1996), which had been criticised equally by small peasants and plantation owners for favouring large plantations. However, other forms of forced labour superseded the renting-out practice. In Mississippi, this happened in 1894 via state-owned prisons and farms (Oshinsky, 1996). In Georgia, the system persisted until 1909 and was then replaced by the chain gang prison system, where prisoners would have to carry out infrastructural work while being chained to each other (Lichtenstein, 1997). These practices only came to an end in the course of the 1960s civil rights movement.

In the Northern states the electorate in the state of New York in 1883 voted in favour of abolishing the contractual labour system. Next to bourgeois reformist forces, which rejected this system as being "un-republican", it has been mainly trade unions agitating against unfair competition. The loss of private demand presented the prison authorities with the challenge of how to discipline the prisoners via work. Thus, qualification programmes have been established, leisure-time possibilities created and therapies offered, at least at places where sufficient tax revenues were available. These experiments in the Progressive Era laid the ground for a "new criminal law science" of re-socialisation, which gained leverage with the New Deal of the 1930s. The exertion of brute force was replaced by the "managerial" concept of rewarding good conduct with early release (McLennan, 2008: 378).

In 1930, shortly before the New Deal and in reaction to the Great Depression, the SmootHartley Tariff Act legislated an import ban on goods produced by forced and compulsory labour. The US government was also a driving force for Convention No. 29 of the International Labour Organisation (ILO), adopted in the same year, which principally bans forced and compulsory labour. In due course, prison labour was forbidden within the United States as "unfair competition" to the free labour market - a success which can be primarily ascribed to the relatively strong industrial trade unions and smaller enterprises potentially in competition with the products of prison labour.

Throughout the entire Fordist era - that is, for more than three decades (until 1975) - the number of inmates remained relatively stable between 150000 and 200000 . The per-capita incarceration rate stayed at approximately one per thousand (Western and Pettit, 2010). Bourgeoisliberal rights such as fair and equal treatment in court, protection through the Constitution and the prohibition to take another person's freedom or life without proper court procedures have been extended during the post-war period.

Thus, the similar outlook on prison labour of progressive bourgeois reformists, trade unions and those companies whose methods of production and personnel management were no longer dependent on direct force has contributed to a fundamental reform of statutory offences and punitive conduct. In the transition from extensive accumulation, accompanied by physical force, towards intensive accumulation, steered by the rhythm of machines - that is, from formal to real subsumption - governmental disciplining techniques also changed. In the context of policies against crime, one can 
speak about a specific period of Fordist Welfare, at least with regard to what was claimed. In an increasingly liberal social climate, underpinned by growing prosperity and improved social security, prison labour seemed to be overcome for the first time in US history.

The relative loss of importance of the prison as a focal point of societal disciplining was not limited to the United States. Especially within European states the number of prisons decreased during the Fordist period and reached a historic minimum in many places (De Giorgi, 2006: 90).

\section{After the Civil Rights Movement: Blacks into Prisons}

The impressive success of the civil rights movement, and the adoption of the civil rights laws in 1964, was followed soon by severe conflicts between some people of black and white skin colour in the North of the United States. Agricultural mechanisation in the South released many black peasant families, who migrated to the North's and the West Coast's industrial cities, attracted by the Fordist demand for labour and the less discriminating social climate. Having arrived there, it quickly became obvious that, despite the now-secured civil rights, many of them were still being prohibited from participating in the American Dream of equal opportunities. Particularly after the murder of the most prominent civil rights activist, Martin Luther King, in 1968, protests erupted in many ghettos of the Northern states' metropoles. These degenerated into violence, not least because of the brutal behaviour of then almost exclusively white police forces.

In reaction to these "riots", the exodus of the white population from the inner cities began to speed up. The attempt to overcome the ensuing renewed segregation of black and white through the mixing of schools by providing bus transport for pupils from one quarter of the city to the other, triggered heavy protests on the side of the white population (Sears and Kinder, 1985). At the same time, owing to different factors, including the large birth cohorts of young people (the so-called baby boom), easier access to drugs and the return of demoralised soldiers from the Vietnam War, the criminal rates of metropoles were rising. Whereas the number of homicides in the 1950s was slightly below 5 per 100000 inhabitants per year, these doubled from the mid-1960s till the mid-1970s towards 10 per 100000 inhabitants (Pinker, 2011: 139).

The white majority population interpreted the rising crime rates as a "black" phenomenon. In the 1970s and 1980s, the Republican Nixon and Reagan administrations pursued a "law and order" policy which - supported by the mass media - specifically devoted itself to the "war against drugs" and the incarceration of the "criminal underclass". The public discourse of endorsing civil rights for blacks lost its appeal and the pre-Fordist discourse of "dangerous classes" surfaced again. This time it targeted not workers but black young men (Morris, 2001). This conservative strategy aimed at securing the traditional status differences vis-à-vis the black population. In the words of Michelle Alexander (2010), the "racial hierarchy" was once more secured. With their law-and-order slogans, right-wing politicians succeeded in winning over parts of the white workforce tending to lean towards liberal Democrats. The result was a general shift of the political spectrum towards the right (Davis, 1986). The criminology discourse reflected that shift. The idea of the possibility of re-socialisation seemed increasingly illusory. Instead, experts, large parts of the electorate and politicians considered an enlarged police presence and harsher penalties to be appropriate solutions (Wacquant, 2009). 
Moreover, some parts of the ghetto population, who were especially afflicted with drug-related crimes, supported more repressive prosecutorial policies (Fortner, 2015).

Just as the progressive prison reformers and trade unions had prepared the ground for the Fordist era, the law-and-order propagandists contributed to the turn towards neo-liberalism. Whereas during the first paradigm change the Northern states were the ones to "universalise" their values throughout the United States, this time the Southern states, which had only marginally been integrated into the Fordist welfare state, have "universalised" their racism (Wacquant, 2009: chapter 2). Although the Southern states had to give up their formal discrimination of Afro-Americans, not only were their policies of excluding trade unions and their meagre social and educational expenditures spreading over the whole country, their practice to brand black people as criminals was diffusing as well.

\section{Repressive Laws: Explosion of the Number of Prisoners}

Since the mid-1970s the number of inmates has been rising in unprecedented numbers, from approximately 200000 in 1975 to 2300000 in 2013 (Carson, 2014). On top of this, there are approximately 5 million more people today who do not serve time in prison only because of caution money or probation, but are nevertheless under penal control (The Sentencing Project, 2015). This expansion of the penal state was much driven by the widening of statutory offenses for non-violent delicts (such as drug abuse and public urination) and increased minimum penalties.

The principle of "indeterminate sentencing" prevailed since the 1920s. Prison terms were imposed for a range of years (e.g. two to ten years), and delinquents could be set free on probation due to their "good" behaviour or "re-socialisation" progress. At the end of the 1970s and the beginning of the 1980s, this principle was abandoned in most states and replaced by relatively precise terms of prison ("determinate sentencing"), where the convicted had to spend the major part of their sentence (between 75 and 100 per cent) in prison ("truth in sentencing"). Furthermore, in 1986 a minimum prison term for drug crime (mostly possession measured in grams) has been determined, yet without considering the extent of damage, the criminal record of the convict or the factual circumstance, and without the possibility of early release (Wacquant, 2009: 65ff.). In the 1990s, a number of state governments significantly increased the sentences for recidivist offenders. In the case of three particularly serious offences, or three offenses which come under this regulation ("threestrikes laws"), the offenders will automatically be sentenced with "life imprisonment" or "25 years up to lifelong" (Wacquant, 2009: 67).

After the first wave of mass incarcerations in the 1980s, the growth of the prison population was increasingly feeding on repeat offenders. Toughened conditions of probation enabled the renewed criminalisation and repeated imprisonment of former prisoners. Overdrawing one's account with a few hundred dollars, for example, could result in renewed imprisonment for several years for convicts on probation. Nearly half of the 423000 detainees who were released in 1998 were back in jail shortly thereafter due to a violation of their conditions of probation. 


\section{Taking Blacks to Prison}

Especially the much-invoked "war against drugs" significantly discloses the racist dimension of the mass incarcerations. In 1975 approximately 27 per cent of detainees in federal prisons were convicted of a drug-related offence. Only ten years later this number was already at 34 per cent, in 1990 at more than 50 per cent and in 1995 at about 61 per cent (Wacquant, 2002: 63). The group of people being imprisoned because of substance abuse did not at all reflect the actual proportions of drug consumers. Whereas the Afro-American population only constitutes 13 per cent of drug consumers (roughly corresponding to their demographic weight), they represent one-third of all imprisoned persons and three-quarters of all those who were imprisoned because of drug-related offenses. Therefore, the probability for a black man to be incarcerated for a delinquency related to drugs is more than twentyfive times higher than for a white man (Wacquant, 2009: 61). The difference between cocaine powder and crack played a major role. Crack was easier to produce and, therefore, more popular in the AfroAmerican ghettos. In contrast to cocaine powder, the ownership of just a few grams of crack was punished with long minimum prison terms. In 1995, for the first time in the country's history, the majority of the prison population was black, although blacks at this time constituted only 12 per cent of the general population (Wacquant, 2009: 61).

The growing (educational) inequality between black and white groups of the population contributed significantly to an increase of the black prison population. Due to the exodus from the cities by many American companies since the 1960s, the municipalities' tax revenues were rapidly shrinking. As a result, they lacked the means for maintaining the traditional standards in public schools. At the same time the more affluent white people were increasingly moving into the suburbs and sending their children to private schools more often. Already in 1989, every fifth white child between the ages of four and fifteen was attending a private school (Duster, 1999: 184f.). The lack of a good education excluded many black youth from the regular labour market. Without good job prospects, a significant proportion of young African-American men turned to illegal activities and ended up in prison. In 2008, 37 per cent of the 20 to 34 age group had been imprisoned, more than those with a job (26 per cent) (The Pew Charitable Trusts, 2010: 3; Western and Pettit, 2010: 10). Critical voices are even speaking of a "School-to-Prison Pipeline" (Kilgore, 2015: 119ff.).

Moreover, during the last decade the spectrum of target groups for imprisonment has been extended. Besides the war against drugs, the "war against illegal immigration" is increasingly filling up US prisons. Since 2006, migration offenses represent the most common reason for detentions and criminal trials. The proportion of non-US citizens in prisons has grown to one-quarter (Kilgore, 2015: 24).

\section{Disciplining the Marginalised}

The transition from the punishing state - that is, the gradual and comprehensive expansion of criminal persecution and mass incarcerations - is closely linked to the cuts in state welfare spending and welfare's neo-liberal restructuring (Wacquant, 2009). A study by Beckett and Western (2001) attests that, especially in states with traditionally lower social security benefits or with strong cuts into the social security net, the prison population was disproportionately large). 
While social programmes aim at social peace, prisons serve as deterrents with the objective of disciplining. The prison, as emphasised by Michelle Alexander (2010: 208), is an expression of "social disapproval" towards groups with little success in the labour market. It is denigrating them morally as well as factually (the denial of voting rights) ${ }^{1}$ to second-class citizens.

The deterrent, disciplining moment of this policy of mass incarceration consists first of all in the demonstration of the lack of alternatives to precarious working and living conditions, which cannot be circumvented - neither by "hanging around in the streets" nor by profitable illegal deals (drug trafficking). Those who resist the disciplining of the work society have to expect prison. However, taking into account the high number of repeated detentions, the deterrent effect, particularly for the male black population, should not be over-estimated. For those, direct disciplining has priority. The deterrent effect of the mass incarceration policy and the compliance-creating pressure for those who have not been imprisoned, might turn out to be larger for migrants without residence permits.

Historically, the justifications for mass incarceration were not entirely novel. In his works, Bernard Harcourt (2011: 271ff) impressively shows the parallels between (market) liberal discourses of the nineteenth century and the expansion of the prison regime at that time on the one hand, and the rise of mass incarceration in the 1970s and 1980s under the teachings of the neo-liberal "Chicago School" on the other hand. Moreover, the rather recent history of mass incarceration shows that a free market discourse and increasing public investments in the penal system only seem to preclude one another.

\section{The Liberal Paradox and the Outsourcing of Costs}

The consistent disciplining of "superfluous workers" (Gans, 2012) via mass imprisonment resulted in a neo-liberal paradox. Although "small government" was at the centre of neo-liberal restructuring, the expenditures for security and prisons were rising steeply. The budget of police, justice and the penal system tripled between 1982 and 2002. Expenditures for the penal system alone, mostly for the construction and maintenance of prisons, increased from approximately US\$20 billion in 1982 to US\$75 billion in 2002 (based on inflation-adjusted prices of 2007) (Bureau of Justice, 2017).

Municipal and state budgets were increasingly put under pressure. Eventually, the costs for the maintenance of prisons per person surpassed the college fees of Ivy-League universities such as Harvard (Kilgore, 2015: 12). Strategies to manage the cost pressure have been diverse. In addition to overcrowding, opportunities for training and rehabilitation were cut. From there it was only a small step to propose the utilisation of the prisoners' labour power as a source of income.

The discourse on financing prisons and their detainees moved from "public assistance" to "selffinancing". Prison inmates are now expected to contribute their own share to the costs of their imprisonment. In neo-liberalism the detention itself is becoming a self-inflicted penalty for which the prisoner (including relatives) has to literally pay: processing charges for visits, rents for bed, and cofinancing for medical care or other "services" such as electricity and laundry. In many cases prisoners are released with bills for prison services of several thousand dollars (Levingston, 2007). In addition,

${ }^{1}$ More than 6 million people in the US have lost their right to vote due to an entry in their police record. 
the neo-liberal idea that private companies perform public tasks more cost-efficiently gained dominance, also regarding the operation of prisons.

\section{The Re-commodification of Prison Labour}

The Prison Industry Enhancement Certification Program (PIECP) of 1979 established the legal framework for private companies contracting prison labour and operating prisons themselves. The Percy Amendment of the same year legalised the sale of prison goods under limited conditions. Influential interest groups like the American Legislative Exchange Council (ALEC), founded in 1973 as an association of conservative entrepreneurs and politicians, supported the policy of mass incarceration and demanded to legalise the exploitation of the prisoners' labour power (Thompson, 2012: 41).

The number of prisoners working for private companies, however, remained rather low at federal prisons. There were never more than 30000 prisoners employed in the two main federal prison labour programmes. The PIECP allows private companies such as Boeing, Starbucks, Victoria's Secret and others to contract with public prisons, but it employed only about 4700 inmates in 2015. This rather low demand for prison labour is not the least the result of strict transparency requirements. The programme's administrators not only have to document and publish the exact number of prisoners working for a wage, but also the name of their employers. Moreover, trade unions and local companies have to be consulted before the contract is signed. Participating companies are obliged to pay the minimum wage. The prisoners, however, are not paid the minimum wage. The effective wage is reduced by about 60 per cent through deductions for taxes, accommodation and meals, and for the support of crime victims' families as well as for the victims themselves. Many of these requirements reflect the anxiety of the Fordist era about the competition from prison labour. The participating companies, however, may promote their products made in prison with the label "Made in America" (Lichtenstein, 2015).

Besides the PIECP, the governmental prison industry company UNICOR is one of the biggest industrial employers for prison inmates on a federal level. In 2015, it employed more than 12000 detainees, down from 21000 in 2008. In other words, nearly every fourteenth federal prisoner works for UNICOR. The detainees primarily produce clothes and textiles, electronic goods and office furniture, which are mostly sold to governmental authorities (FPI, 2014: 9). Since 2012, however, UNICOR may also sell to private firms under certain conditions. This business branch is only in its infancy. By far the largest purchaser remains the Defense Department. UNICOR manufactures uniforms, (parts of) weapons, radios and communication tools for hourly wages of US $\$ 0.23$ up to US\$1.15 in the prisons (Urbina, 2014: 110f.; Wood, 2015). Significantly worse working conditions than on the free labour market are reported, even though trade unions are integrated into these work programmes and certain requirements exist (such as formally voluntary participation). For example, federal investigators detected a lack of safety and health provisions at facilities recycling electronic waste and manufacturing intermediate products for missiles for the military (Sample, 2009).

The majority of the more than 2 million prisoners in the United States live and work not in the

prisons operated by the Federal Bureau of Prisons (BOP), however, but in state prisons and jails run 
by municipalities (about 70 per cent). Almost all of the fifty states have, following the PIECP, adopted similar legislation, although oftentimes with significantly fewer transparency regulations and without requirements such as paying minimum wage. Thereby, a patchwork of decentralised, profit-oriented prison industries has developed in the last decades. It is estimated that at least one-tenth of all detainees in the United States work in different prison industries (their share in the prison population able to work is higher, since the overall population also includes the chronically ill, minors and retirees). Available data on prison labour in the US is, however, very opaque for two main reasons. On the one hand, government agencies collect and publish little data on industrial prison labour. While statistics on the demographics of prisoners and reasons for their detention do exist, no information is provided on the number of worked hours, net wages or the concrete working conditions. On the other hand, the prison system is divided into different levels: Besides prisons which are operated by the federal government or the Federal Bureau of Prisons, a majority of detainees serve in jails operated by individual states with their own laws on work in prisons. Additionally, people are doing time in local jails which are in the charge of municipal administrations. Furthermore, the growing number of privately operated prisons (currently ca. 10 per cent) has to be taken into account; their role will be elaborated on in the next section. The depiction of prison labour is thus very dependent on the reports of investigative journalists.

In Colorado, for instance, about 1600 prisoners were employed in thirty-seven different industrial sites in 2014; that is approximately 15 per cent of the prison population were able to work. The production reaches from the manufacture of furniture, licence plates and flags, to agricultural produce such as dairy products, fish farming and vegetable cultivation through to services such as car repair, construction and landscape gardening. Workers received an average daily wage of US\$3.95 in 2014 (Colorado Office of the State Auditor 2015: 9-11). Thus, the hourly wage, assuming a four-hour working day, remains under US1.00. Other states give a similar picture. In 2014, 1600 prisoners were employed at forty-five production sites of the Washington State Correctional Industries. The workers represented roughly ten per cent of inmates in the State of Washington and were working, like in Colorado, for hourly wages of US\$0.55 on average (Berens and Baker, 2014). These low production costs enabled by the exploitation of prison labour, resulting in previously outsourced industries coming back to the United States, such as the relocation of maquiladoras at the Mexican-US border (on Mexico's side) towards prisons in California or Texas (Paleaz, 2014). The declared main objective of these governmental, profit-oriented prison industries is to refund, at least partly, the high expenditures of criminal prosecution and the penal system (Berens and Baker, 2014; Colorado Office of the State Auditor, 2015).

The difference between federal and state prisons concerning the extent and the conditions for commercial prison labour is a product of diverging balances of power. Trade unions are stronger at the federal level than in many US states.

Altogether, the commercial exploitation of prison labour, though growing, only affects parts of the prison population. The majority of prisoners work for the preservation of the prison itself (in the laundry, the kitchen or food distribution, help with administrative issues, etc.). Without this work, the system of mass incarceration, financially as well as organisationally, would hardly be operable (Chang and Thompkins, 2002: 56).

Global Labour Journal, 2017, Issue 8(1), Page 41 


\section{The Privatisation of Prisons and Profiting from Migration}

The privatisation of many prisons, which created a new business opportunity, proceeded parallel to the re-commodification of prison labour. Within three decades the private prison sector was growing rapidly and is now guarding about one-tenth of all prisoners. Among the companies, a few major corporations are dominant, particularly the GEO Group and the Corrections Corporation America (CCA), which taken together register annual profits of US\$3 billion; they are listed on the New York stock exchange. Additionally, a broad network of companies exists which benefits from mass incarcerations and the prison boom. Between 2001 and 2012 the average yearly expenditure only for the construction of prisons amounted to almost US $\$ 3$ billion. These large-scale infrastructural projects are important sources of income for many regions, particularly those affected by high unemployment and poverty (Thorpe, 2015). Besides construction companies, other industries are profiting from the prison boom; these include financial institutions supplying the necessary finance, security firms, health service providers, and transport companies which specialise in the supply of prison meals (Herivel and Wright, 2007). The term "prison-industrial complex" has been coined for the increasing importance of profit-oriented firms in the prison sector and their interlocking with industrial production, governmental authorities and political elites (Friedmann, 2012; Thompson, 2012). Political representatives in rural areas with large prisons belong to the most vehement advocates of more severe penal legislation (Thorpe, 2015).

Although private companies own and operate the prisons, they are paid per prisoner on a daily or monthly basis by governmental agencies such as the Federal Bureau of Prisons, Immigration and Customs Enforcement (ICE) and the US Marshall per prisoner (Kilgore, 2013; The Geo Group, 2013). Besides the construction of new prisons, private investors also purchased prisons from municipalities, regional or federal governments (Chang and Thompkins, 2002: 49). Privatisation has not resulted in savings for tax payers despite the paring down of personnel, declining wages, lower fringe benefits and the elimination of training possibilities for employees - circumstances which have been criticised by trade unions for years (Quinell, 2014).

Especially the business with migration has developed into a profitable branch for private companies in the last years. The mandatory detention in the case of migration offences, which was introduced in 1996, resulted in a rapid expansion of deportation centres. While in 1981 only a dozen detention centres existed, their number grew to more than 200 by 2011, with a daily average population of over 32000 (Kilgore, 2015: 83). While just under one-tenth of all prisoners serve time in private prisons, 40 per cent of all immigration detention prisons in the US are privately operated. One-third of those detention centre capacities are provided by the two major corporations - CCA and GEO Group. In 2012, CCA and the GEO Group concluded contracts for deportation jails with federal authorities worth US\$738 million. The government pays for the prisoners as long as the companies meet a minimum quota (since 2013 this amounts to 34000 detainees at any moment) (Kilgore, 2015: 85). Thus, there is an incentive to detain as many people as possible, for as long as possible based on migration offenses.

The interest in large numbers of prisoners drives the prison companies' lobbying activities. The 
three biggest prison companies spent US $\$ 40$ million on lobbyism in the last ten years, chiefly to convince Republicans to tighten immigration laws and introduce a general identity card requirement (Friedmann, 2012). In 2010, for instance, the private prison industry was actively involved in the drafting and passage of one the most controversial, broadest and strictest anti-illegal immigration measures in the United States at that time - Arizona's Senate Bill 1070 (Detention Watch Network, 2011). Moreover, former Speaker of the Florida House of Representatives, Marco Rubio, awarded a US $\$ 110$ million contract to the GEO Group, and chiefly worked on a comprehensive bill calling for stricter immigration laws and tighter controls of "illegal migration" (Cohen, 2015). Thereafter, his election campaign was financially supported by the GEO Group (Walsh, 2016).

Information about the working conditions in the immigration detention prisons are solely provided by newspaper reports. Cases have become repeatedly known where migrants were forced to work either without payment or for daily wages below US\$1.00 (Planas, 2015). According to estimations, all in all 60000 migrants are working in "voluntary" labour programmes for less than US $\$ 1.00$ daily wage in private as well as in publicly operated institutions (Urbina, 2014).

\section{Critique of Prison Labour}

Prison labour is not without contradictions and does not go uncontested. While the extent of prison labour has been increasing in the United States, criticism against Chinese prison labour has been levelled towards China again and again within the international trade discourse. This critique has even been institutionalised: according to Public Laws 106-398 and 108-7, Congress has to be regularly informed about Chinese prison labour. This discourse, however, is completely divorced from the discourse on US prison labour - the criticism towards China does not lead to questioning one's own practices (Cowen, 1993; Whyte and Baker, 2000). In fact, prison labour practices in the United States generally receive little attention in the American media.

Changes in prison labour practices might be brought about by the inmates themselves. Recently, several attempts at organising have been reported. In September 2016, the Formerly Incarcerated, Convicted People and Families Movement (FICPFM) together with the Incarcerated Workers Organizing Committee (IWOC) has held a conference on mass incarceration and the exploitation of prison labour. At the same time, prisoners required to work went on strike in a number of prisons. Unfortunately, they failed in their objective to put the topic of prison labour onto the agenda of the presidential elections. The media mostly ignored the strikes.

At the federal level, the Obama administration took some measures against some of the most discriminatory aspects of criminal law. It minimised the difference between the penalties for crack and cocaine powder. In order to avoid minimum sentences, the amount of drugs found in the possession of the offenders is no longer mentioned by the prosecutors. And very recently the Obama administration decided not to renew the contracts with private prison corporations. This positive trend will most certainly end with the Trump administration. Donald Trump's harsh rhetoric against migrants has already led to a stock market rally for the private prison corporations (Speri, 2016). 


\section{Conclusion: Prison Labour at the Intersection of Neo-liberalism and Race}

Over the last century, policies of incarceration and the treatment of prisoners have mirrored general shifts in the political and economic organisation of society. In the era of Fordism, rehabilitation of delinquent persons dominated the criminal justice discourse, while incarceration numbers were at their lowest historical level. In neo-liberal times, rehabilitation as a general principle has been marginalised and has made way for the free market ideology. Accordingly, imprisonment is deemed self-inflicted and delinquent behaviour is isolated from its societal context - that is, from the political, economic and cultural conditions upon which it rests. Since it is self-inflicted, inmates are expected to finance the costs of their own detention through work. The trade union movement, which had successfully fought prison labour for commercial purposes during Fordism, has become too weak at the state level to prevent this type of labour exploitation.

While providing employment for all who wanted to work was an explicit goal under Fordism, in the age of neo-liberalism welfare and labour market policies force as many people as possible into the job market without providing sufficient jobs. In the resulting competitive environment, many persons fall to the wayside. From the viewpoint of the employers these people are "expendable", and from the viewpoint of many wage earners they are "undeserving". Both viewpoints consider the reasons for joblessness as self-inflicted and not as a consequence of historical or current discrimination. Accordingly, the disciplining of the "superfluous workers" is accepted or even demanded. Moreover, the prison regime is casting a shadow on those for whom there is actually demand in the labour market but who are only employed under precarious conditions. Due to high sentences and the subsequent societal stigmatisation, more profitable employment outside of legality has become an utterly risky alternative. The majority of the precariously employed are left with no other options.

Disciplining through imprisonment, however, is expensive. In line with the overall tendency towards "personal responsibility", it comes naturally to let prisoners generate parts of their accommodation costs through work, and to transfer the prisons' administration to the allegedly more efficient private sector. This shift, legally secured since 1979, has created a new actor field interested in the expansion of prison labour. This field is constituted by governmental providers of the mostly still publicly operated prisons and the new private prison companies as well as by the governmental and private purchasers of the prisoners' products. Private prison operators even promote a stricter deportation policy, so that they can exploit healthy migrants for a couple of months.

Without the legacy of slavery and the ensuing racism, however, US incarceration and prison labour policies cannot be understood. The widespread racism towards persons with black skin colour has led to a disproportionately high imprisonment of especially black men - frequently for offences which are owed to their discrimination in the labour market. Racism also effects the elimination of the large prison population from public discourse, only occasionally disrupted by mass protests against police violence. Although the United States is predominantly an immigrant society, the migration of foreigners is highly contested. Currently, a significant part of the American population opposes migrants coming from south of the Rio Grande. The periodically occurring repressive measures against people without residence permit mostly remain without resonance in the media, and their fate in deportation jails is likewise not part of public awareness. Having mobilised racist resentments in the election campaign, the incoming Trump administration will most likely rescind the belated measures 
by the Obama administration against the worst forms of discrimination in the penal system.

In sum, the evolution of prison labour has to be seen in the context of societal phases with their specific ideology, modes of production and balance of forces, and has to take into account the specific conditions of the labour market as well as the discrimination of specific social groups in society whose citizenship is questioned by a dominant segment of the population.

\section{REFERENCES}

Alexander, M. (2010) The New Jim Crow: Mass Incarceration in the Age of Colorblindness. New York: The New Press.

Beckett, K. and B. Western (2001) Governing Social Marginality. Welfare, Incarceration, and the Transformation of State Policy. Punishment \& Society, 3(1): 43-59.

Berens, M.J. and M. Baker (2014) Broken Prison Labor Program Fails to Keep Promises, Costs Millions. The Seattle Times, 13 December 2014. Available online at http://projects.seattletimes.com/2014/prisonlabor/1/ [accessed 22 October 2015].

Bureau of Justice (2010) Direct Expenditures by Justice Function, 1982-2007. Available online at http://web.archive.org/web/20120101181331/http://bjs.ojp.usdoj.gov/content/glance/tables/exptypta b.cfm [accessed 26 September 2015].

Carson, A.E. (2014) Prisoners of 2013. Bureau of Justice Statistics Bulletin, 30 September 2014. Available online at http://www.bjs.gov/content/pub/pdf/p13.pdf [accessed 26 September 2015].

Cerny, P.G. (2008) Embedding Neoliberalism. The Journal of International Trade and Diplomacy, 2(1): 1-46.

Chang, T.F. and D.E. Thompkins (2002) Corporations go to Prisons: The Expansion of Corporate Power in the Correctional Industry. Labor Studies Journal, 27(1): 45-69.

Cohen, M. (2015) How For-profit Prisons have become the Biggest Lobby No One is Talking About. The Washington Post, Available online at https://www.washingtonpost.com/posteverything/wp/2015/04/28/how-for-profit-prisons-havebecome-the-biggest-lobby-no-one-is-talking-about [accessed 16 August 2016].

Colorado Office of the State Auditor (2015) Department of Corrections. Colorado Correctional Industries. Performance Audit, January 2015.2 Available online at http://www.leg.state.co.us/OSA/coauditor1.nsf/All/908C1FE0217F7E0487257DCE00701378/\$FILE/ $1350 \mathrm{P} \% 20$ Colorado $\% 20$ Correctional $\% 20$ Industries, $\% 20$ Department $\% 20$ of $\% 20$ Corrections, $\% 20$ January \%202015.pdf [accessed 22 October 2015].

Cowen, J.M. (1993) One Nation's “Gulag” is Another Nation's "Factory within a Fence”: Prison Labor in the People's Republic of China and the United States of America. Pacific Basin Law Journal, 12(1): 191-236.

Davis, M. (1986) Prisoners of the American Dream. London: Verso.

De Giorgi, A. (2006) Re-Thinking the Political Economy of Punishment. Perspectives on Post-Fordism and Penal Politics. Hampshire: Ashgate.

Detention Watch Network (2011) The Influence of the Private Prison Industry in the Immigration Detention Business. Available online at http://www.detentionwatchnetwork.org/sites/default/files/reports/DWN $\% 20$ Private $\% 20$ Prison $\% 20 I n f$ luence\%20Report.pdf [accessed 26 August 2016].

Dodge, C. (ed.) (1975) A Nation without Prisons: Alternatives to Incarceration. Lexington: Lexington Books. 
Duster, T. (1999) Gefängnis statt Arbeit: Ausgrenzung schwarzer Jugendlicher. In Jobwunder USA - Modell für Deutschland, edited by S. Lang, M. Mayer and C. Scherrer. Münster: Westfälisches Dampfboot.

Federal Prison Industries Inc. (FPI) (2014) Fiscal Year 2014. Annual Management Report, 12.November 2014. Available online at https://www.unicor.gov/information/publications/pdfs/corporate/2014\%20FPI\%20Annual $\% 20 \mathrm{Manag}$ ement $\% 20$ Report_C.pdf [accessed 26 September 2015].

Fortner, M.J. (2015) Black Silent Majority. Cambridge: Harvard University Press.

Friedmann, A. (2012) The Societal Impact of the Prison Industrial Complex, or Incarceration for Fun and Profit - Mostly Profit. Prison Legal News, 15 January 2012. Available online at https://www.prisonlegalnews.org/news/2012/jan/15/the-societal-impact-of-the-prison-industrialcomplex-or-incarceration-for-fun-and-profitmostly-profit [accessed 26 September 2015].

Gans, H. (2012) Superfluous Workers. Challenge, 55(4): 94-103.

Garland, D. (1985) Punishment and Welfare. Aldershot, Hants: Gower.

Garland, D. (1990) Punishment and Modern Society. Chicago: University of Chicago Press.

Harcourt, B. (2011) The Illusion of Free Markets. Punishment and the Myth of Natural Order. Cambridge: Harvard University Press.

Herivel, T. and P. Wright (eds.) (2007) Prison Profiteers: Who Makes Money from Mass Incarceration? New York: The New Press.

Kilgore, J. (2013) The Myth of Prison Slave Labor Camps in the U.S. Counterpunch, 9-11 August 2013. Available online at http://www.counterpunch.org/2013/08/09/the-myth-of-prison-slave-labor-camps-in-the-u-s [accessed 23 September 2015].

Kilgore, J. (2015) Understanding Mass Incarceration. A People's Guide to the Key Civil Rights Struggle of our Time. New York: The New Press.

Laclau, E. (1990) New Reflections on the Revolution of Our Time. London: Verso.

Levingston, K.D. (2007) Making the "Bad Guy" Pay: Growing Use of Cost Shifting as an Economic Sanction. In Prison Profiteers. Who makes Money from Mass Incarceration, edited by T. Herivel and P. Wright. New York: The New Press.

Lichtenstein, A. (1997) Twice the Work of Free Labor: The Political Economy of Convict Labor in the New South. New York: The Free Press.

Lichtenstein, A. (2015) Using US Prison Labour to Make Crime Pay. Open Democracy, 22 April 2015. Available online at https://www.opendemocracy.net/beyondslavery/alex-lichtenstein/using-us-prison-labour-tomake-crime-pay [accessed 25 September 2015].

Melossi, D. and M. Pavarini (1981) The Prison and the Factory. London: Macmillan.

Mancini, M.J. (1996) One Dies, Get Another: Convict Leasing in the American. South, 1866-1928. Columbia: University of South Carolina Press.

McLennan, R.M. (2008) The Crisis of Imprisonment: Protest, Politics, and the Making of the American Penal State, 17761941. New York: Cambridge University Press.

Morris, L. (2001) Dangerous Classes: The Underclass and Social Citizenship. New York: Routledge.

Oshinsky, D.M. (1996) Worse Than Slavery. Parchman Farm and the Ordeal of Jim Crow Justice. New York: Free Press.

Pelaez, V. (2014) The Prison Industry in the United States: Big Business or a New Form of Slavery. Global 
Research, 31 March. Available online at www.globalresearch.ca/the-prison-industry-in-the-united-states-bigbusiness-or-a-new-form-of-slavery/8289 (accessed on 22 October. 2015).

Pinker, S. (2011) The Better Angels of Our Nature: A History of Violence and Humanity. London: Penguin.

Planas, R. (2015) Private Prison Company Forced Immigrants To Work for Free, Lawsuit Says. Huffington Post, 10 July 2015. Available online at http://www.huffingtonpost.com/entry/private-prison-immigrantdetainees 559eee31e4b05b1d02900daa [accessed 26 September 2015].

Price, K., A. Pierson and S. Coleman (2012) Sentenced to Work. From Retribution to Rehabilitation. Internet Journal of Criminology, Available online at http://www.internetjournalofcriminology.com/Price_Pierson_Coleman_Sentenced\%20to\%20Work_IJC Oct 2012.pdf [accessed on 26 September 2016].

Quinell, K. (2014) You Know What Doesn't Work so Well? Private Prisons. AFL-CIO Blog, 10 April 2014. Available online at http://www.aflcio.org/Blog/Corporate-Greed/You-Know-What-Doesn-t-Work-SoWell-Private-Prisons [accessed 22 October 2015].

Rusche, G. and O. Kirchheimer (1968 [1939]) Punishment and Social Structure. New York: Russel \& Russel.

Sample, B. (2009) Prisoners Exposed to Toxic Dust at UNICOR Recycling Factories. Prison, Legal News, 15 January. Available online at https://www.prisonlegalnews.org/news/2009/jan/15/prisoners-exposed-totoxic-dust-at-unicor-recycling-factories [accessed 22 October 2015].

Sears, D.O. and D.R. Kinder (1985) Whites' Opposition to Busing: On Conceptualizing and Operationalizing Group Conflict. Journal of Personality and Social Psychology, 48(5): 1141-1147.

Schmiede, R. (1988) Reelle Subsumtion als gesellschaftstheoretische Kategorie. In Zur Entwicklungsdynamik des modernen Kapitalismus: Beiträge zur Gesellschaftstheorie, Industriesoziologie und Gewerkschaftsforschung, Symposium für Gerhard Brandt, edited by W. Schumm. Frankfurt am Main: Campus Verlag.

Speri, A. (2016) Private Prisons Were Thriving Even Before Trump was Elected. The Intercept. Available online at $\quad$ https://theintercept.com/2016/11/28/private-prisons-were-thriving-even-before-trump-waselected/?comments=1\#comments [accessed 3 January 2017].

The GEO Group (2013) 2013 Annual Report. Available online at http://www.geogroup.com [accessed 26 September 2015].

The Pew Charitable Trusts (2010) Collateral Costs: Incarceration's Effect on Economic Mobility. Washington, DC: The Pew Charitable Trusts.

The Sentencing Project (2015) The State of Sentencing 2014. Developments in Policy and Practice. Washington, DC: The Sentencing Project.

Thompson, H.A. (2012) The Prison Industrial Complex: A Growth Industry in a Shrinking Economy. New Labor Forum, 21(3): 38-47.

Thorpe, R.U. (2015) Perverse Politics: The Persistence of Mass Imprisonment in the Twenty-first Century. Perspectives on Politics, 13(3): 618-637.

Urbina, I. (2014) Using Jailed Migrants as a Cheap Pool of Labor. New York Times, 24 May 2014. Available online at http://www.nytimes.com/2014/05/25/us/using-jailed-migrants-as-a-pool-of-cheap-labor.html [accessed 25 September 2015].

Wacquant, L. (2002) Four Strategies to Curb Carceral Costs: On Managing Mass Imprisonment In the United States. Studies in Political Economy, 69: 19-41.

Wacquant, L. (2009) Punishing the Poor. The Neoliberal Government of Social Insecurity. Durham: Duke University 
Press.

Walsh, M. (2016) Private Prisons Fight Back. Justice Policy. Available online at www.justicepoliy.org/news/10110 [accessed 15 August 2016].

Western, B. and B. Pettit (2010) Incarceration and Social Inequality. Daedalus, 139(3): 8-19.

Whyte, A. and J. Baker (2000) Prison Labor on the Rise in US. Available online at www.wsws.org/en/articles/2000/05/pris-m08.html (accessed 23 September 2015).

Wood, G. (2015) From our Prison to Your Dinner Table. Pacific Standard Magazine, 3 March 2015. Available online at http://www.psmag.com/business-economics/from-our-prison-to-your-dinner-table [accessed 25 September 2015].

Wullweber, J. and C. Scherrer (2011) Post-modern and Post-structural International Political Economy. In The International Studies Encyclopedia, edited by R.A. Denemark. Oxford: Blackwell, Blackwell Reference Online.

\section{BIOGRAPHICAL NOTES}

CHRISTOPH SCHERRER, economist and political scientist, is professor of globalisation and politics and Executive Director of the International Center for Development and Decent Work at the University of Kassel and a member of Steering Committee of the Global Labour University. Forthcoming publication: Public Banks in the Age of Financialization: A Comparative Perspective, Cheltenham: Edward Elgar. [email: Scherrer@uni-kassel.de]

ANIL SHAH was a research assistant at the subdivision "Globalization and Politics" of the Department of Politics at the University of Kassel. He has an interest in theories of global political economy and socio-ecological research. He recently published his master's thesis, "Destructive Creation: Analyzing Socio-Ecological Conflicts as Frontiers of Capitalist Development" as a working paper. [email: anil.shah@posteo.de] 